\title{
Empirical Study of Forest Regeneration Potentiality of Old Afaka Forest Reserve, Kaduna State, Nigeria
}

\author{
Sodimu Akintunde Isiaka*, Olorukooba Mojishola Marliyat, Osunsina Olujide, Suleiman Rukayat \\ Federal College of Forestry Mechanization, Forestry Research Institute of Nigeria, PMB 2273, Afaka-Kaduna, Nigeria
}

*Corresponding Author

Sodimu Akintunde Isiaka

\author{
Article History \\ Received: 06.09.2020 \\ Accepted: 14.09 .2020 \\ Published: 20.10 .2020
}

\begin{abstract}
Forest Reserve Areas can sustain themselves of their valuable species through an effective regeneration system. At present, most of the preserved forest areas are been vandalized and valuable species are illegally removed. Based on the ecological problems which lead to the extinction of valuable flora and fauna species, it became necessary to study species diversity and their potentiality for regeneration in old Afaka Forest Reserve. Four (4) plots (A-D) of 100m $\mathrm{x} 100 \mathrm{~m}$ were laid in each plot. Point centred quadrant method of sampling was used. Transect were selected on pure random basis where data were collected on species diversity and families, density of woody stem, diameter class distribution, regeneration potentials and relative frequency. 21 families with a total of 181 species were obtained on the species diversity at old Afaka Forest Reserve. The densities of woody plant varied between 625.01 - 961.51 per hectare in plots $\mathrm{A}, \mathrm{B}, \mathrm{C}$ and $\mathrm{D}$. While the highest number of trees in diameter-class distribution were apportioned to $10-19 \mathrm{~cm}$ class interval in plots A, B, C and D respectively. Diameter class $50 \mathrm{~cm}$ and above had the lowest number of trees allocated to it. The regeneration potential of the diversified species was very poor, which has a great implication for regeneration and conservation of the various species encountered. Although Isoberlinia doka Craib \&Stapf.had the highest regeneration potential from each of the examined plots followed closely by Acacia senegal, Parkia biglobosa and Terminalia avicennoides Gull \&Peer. Important woody plants of economic importance, like Triplochiton scleroxylon $k$. schum had zero regeneration potential. However, it is necessary to understand the phenology of the forest reserve. To study whether seeds or fruits produced are under adequate physiological conditions to germinate and grow into wildlings for regeneration purposes.
\end{abstract}

Keywords: Conservation, Forest regeneration, Forest reserve, Potentiality, point centred, vandalized.

\section{INTRODUCTION}

Biological diversity conservation strategies that include a variety of individual management strategies for specific species are neither feasible nor effective [1-3]. As an alternative, 'coarse-filter' management strategies focus on maintenance of broad patterns of forest age and composition under the assumption that this will provide the necessary habitat to support a wider variety of native species $[4,5]$. Native species are assumed to be adapted to the natural disturbance regime of their environment; thus, management that stimulates the natural disturbance regime has become a popular approach to maintaining species diversity as well as ecological integrity [6, 7]. With this approach, natural processes are to be protected, which include forest regeneration after disturbance such as fire or logging [8]. A central component of biodiversity conservation in managed forest landscape is successful regeneration of natural tree species mixes after logging [9, 10]. This often proves to be a substantial challenge. Site preparation and planning of tree seedlings have been widely adopted as strategies to ensure rapid and successful postharvest regeneration. These require a substantial silvicultural and financial investment, however, and are not always successful in meeting legal regeneration standards let alone achieving a natural species mix. Although natural regeneration can be much less expansive and lead to more natural species mixes, its success depends on availability of seed sources, regeneration micro sites and micro environmental and biotic conditions favoring establishment and early survival of tree seedlings [11, 12].

Copyright (C) 2020 The Author(s): This is an open-access article distributed under the terms of the Creative Commons Attribution 4.0 International License (CC BY-NC 4.0) which permits unrestricted use, distribution, and reproduction in any medium for noncommercial use provided the original author and source are credited. 
There is necessity to conserve the forest resources because of their economic importance. Several direct as well as indirect benefits are available in the forest such as timber and non-timber products. Apart from timber products in the forest, plant foods such as leaves, seed nuts, fruits, tubers and roots stand as source of food income generation [13, 10]. Also, species of economic importance such as medicinal and aesthetic values can be kept in perpetuity in a well preserved forest. The forests of Nigeria comprise of swamp forest, tropical rainforests and secondary forest regrowth. The lowland tropical rainforest was described by as a complicated mosaic of communities of different status and floristic composition [14]. Structurally, the forests consist of three layers - the tree layer, the shrub layer and the undergrowth. Many of the emergent species in the forest grow slowly and require fair amount of overhead shade in their early life in order to survive and thrive $[15,16]$. But it is now recognized that many of them grow very rapidly in full light conditions [17].

The emergent species exist for a long period in a state of suppressed regrowth under shade of the canopy until a gap occurs which allows them to grow up. Forestry growth cycle consists of a mosaic gap-phase, build up phase and mature phase forests as explained by Van der Maarel [18]. At present most of the preserved forest areas are being vandalized and valuable species illegally removed. The only mean by which Forest Reserved Areas can sustain themselves of these valuable species, is through an effective regeneration programmes. NEST [19] indicated that 350,000 ha of forest and natural vegetation were lost in Nigeria. It led to problems such as desertification, soil erosion, declining soil fertility; flooding and extinction of important flora and fauna species [20, 21]. Forests are dynamic, seedlings germinate, grow, and compete with each other and with large trees. Some survive for hundreds of years. Changes will happen which will be predominant in the future forest depends not only on climate and soils but also on management decisions made today. Changes in forest composition will affect the quality and variety of forest resources available to future generations and wildlife [16]. Sustainable management of forest ecosystem is set as a goal by most nations [22, 15], and maintaining biological diversity is one important component of this [23].

High demands for timber and increasing accessibility are leading to increased exploitation of these high elevation forests. They are characterized by slow growth rates of post-disturbance regeneration and established trees. Thus meeting objections for regeneration of natural species mixes and sustainability of fiber and other ecosystem components can prove challenging [24, 25]. The only mean by which Forest Reserved Areas can sustain themselves of these valuable species, is through an effective regeneration programmes. Forest and natural vegetation lost in Nigeria every year due to anthropogenic activities are of great concerned. It led to problems such as desertification, soil erosion, declining soil fertility, flooding and extinction of important flora and fauna species [20]. Hence, necessitate the need to study the natural regeneration potentials of forest reserved areas so that species of economic significance, including nontimber forest products (NTFPs) and aesthetic values, can be maintained in perpetuity. The objective of the study is to assess the species diversity and potentiality for forest regeneration in Old Afaka Forest Reserve.

\section{Materials ANd Methods Study Area}

The study was carried out in Old Afaka Forest Reserve. Afaka is in Igabi Local Government Area. Igabi Local Government Area is located in the Northern Guinea Savanna region of Nigeria on latitude $10^{0} \mathrm{E} 37^{1} \mathrm{~N}$ and $10^{0} 41^{1} \mathrm{~N}$ and longitude $7^{0} 47^{1} \mathrm{E}$ [26] Igabi local Government Area shares boundary with Kaduna South, Kaduna North, Giwa Local Government and Zaria Local Government areas of Kaduna State. It has an Annual rainfall of about 1000mm -1500mm per annum. Major crops grown in the area include maize, cassava, millet, sorghum, guinea-corn and water-melon. The area consists of different tribes and ethnic groups such as Yoruba's, Hausa, Igbo's, Fulani's, Gbagyi's and Hausa's. The area has an estimated population of about 570,00 people and covers an area of about 4556.95 square kilometers [27].

\section{Sampling Procedure}

Four (4) sampling plots of 100m x 100m were laid in Old Afaka Forest Reserve. Technique used was adopted from Cuttam and Curts, 1956 [28]; Oduwaiye et al., 2002 [13]; Sodimu et al., 2017 [29]. Point centred quadrant method of sampling was used in each of the selected plots. Transects were selected using systematic sampling method. The first one was selected on pure random basis. Along the direction of each transect, sampling points were taken at intervals of $5 \mathrm{~m}$ which helps in getting sufficient sampling points and possible overlapping and duplication of units of measurement were avoided [10]. At each sampling point, the following parameters were assessed. Distance to four nearest woody plants, one in such quadrant. 


\section{Height of the tree}

This is measured through the use of Haga altimeter.

\section{Diameter of each tree}

This is measured through the use of diameter tape.

\section{Analytical Tools}

Density

Densities of the woody stem in all the study plots were determined. The distance measured between sample points of each woody plant was used to obtain the density stem. The estimation was based on the formula;

$$
\mathrm{D}=\frac{10^{4} \text { stem }}{\mathrm{d}^{2}} \mathrm{ha}^{-1}
$$

Where $\mathrm{d}^{2}=$ is the average distance in $\mathrm{m}^{2}[28,10]$

\section{Diameter Class Distribution}

Diameter class distribution was determined through the measurement of diameter of the woody stand in all the plots at DBH (1.37m height)

\section{Regeneration Potentials}

Regeneration potential $=$ Number of wilding of individual species

$$
\text { Density of the woody stem }
$$

\section{Relative Frequency}

R.F $=\quad \frac{\text { Number of individual of the species }}{\text { Number of individual of all species }} \times 100$

\section{Species Abundance}

Species abundance, indicating the number of species contained in the number of individual plants.

\section{Results AND Discussion}

\section{Species Diversity and Families}

Members of the families in acceding order include Fabaceae>Combretaceae, Sterculiaceae >Verbanaceae dominated the permanent protected area followed by members of Annonaceae >Rhamnaceae> Anacardiaceae $>$ Meliaceae and to a lesser extent, some other families include Sapotacea>Euphorbiaceae > Ochnaceaeand so on. The species that are most common in acceding order are Isobanilia doka>Parkia biglobosa $>$ Prosopis africana>Vitex doniana > Acacia senegal > Lawsonia inermis Table-1). This result is in agreement with the work of Sodimu et al., [10] that the first four (4) families dominated Old Afaka and Buruku forest Reserve with high percentages spread.

\section{Density}

The density of the woody stem as indicated in Table-2, revealed that plot $\mathrm{C}$ in permanent protected area had 961.51stem/ha which was the highest when compare to plot A, plot B and plot D with 857.64stem/ha, 760.72stem/ha and $625.01 \mathrm{stem} / \mathrm{ha}$ respectively.

\section{Diameter Class Distribution}

Diameter class distribution of woody stems assessed in plot A, B, C and D; however, the number of trees assessed for diameter was $80,125,85$ and 80 respectively. The highest number of trees was apportioned to diameter class $10-19 \mathrm{~cm}$ for each of the plots A, B, C and D, that was 40 trees, 60 trees, 75 trees and 40 trees respectively, followed by diameter class $20-29 \mathrm{~cm}$ (Fig-1). Diameter class $50 \mathrm{~cm}$ and above had the lowest number of trees allocated to it. Perharps, this might be due to over exploitation and activities of illegal fellers in the reserve hunting for trees with bigger girth for conversion into sizeable wood. The above observation was in agreement with the work of Sodimu et al., [10] who also noted that diameter class of trees between $10 \mathrm{~cm}-19 \mathrm{~cm}$ are commonly found in most forest reserves around Kaduna Northern Guinea Savanna eco-zones. 
Table-1: Species Diversity and Families in Old Afaka Forest Reserve

\begin{tabular}{|l|l|l|l|}
\hline S/No & Families & Number of Species & Percentage (\%) Spread \\
\hline 1 & Fabaceae & 28 & 15.4 \\
\hline 2 & Ebenaceae & 6 & 3.32 \\
\hline 3 & Annonaceae & 8 & 4.42 \\
\hline 4 & Anaccardiaceae & 7 & 3.87 \\
\hline 5 & Combretaceae & 15 & 8.28 \\
\hline 6 & Longaniaceae & 5 & 2.76 \\
\hline 7 & Meliaceae & 7 & 3.87 \\
\hline 8 & Rhamnaceae & 7 & 3.70 \\
\hline 9 & Rubiaceae & 6 & 3.87 \\
\hline 10 & Sapotaceae & 8 & 4.42 \\
\hline 11 & Sterculiaceae & 10 & 5.53 \\
\hline 12 & Verbanaceae & 7 & 3.87 \\
\hline 13 & Papilioceae & 8 & 4.42 \\
\hline 14 & Casalpiniaceae & 6 & 3.32 \\
\hline 15 & Myristicaceae & 7 & 3.87 \\
\hline 16 & Ochnaceae & 8 & 4.42 \\
\hline 17 & Irvingiaceae & 10 & 5.53 \\
\hline 18 & Chysobaniaceae & 6 & 3.32 \\
\hline 19 & Euphorbiaceae & 8 & 4.42 \\
\hline 20 & Lythraceae & 8 & 4.42 \\
\hline 21 & Myrtaceae & 6 & 3.32 \\
\hline & TOTAL & $\mathbf{1 8 1}$ & $\mathbf{1 0 0}$ \\
\hline
\end{tabular}

Table-2: Density of Woody Plants at Various Plots in Old Afaka Forest Reserve

\begin{tabular}{|l|l|l|}
\hline S/N & Site & Stem $\left(\mathbf{h a}^{\mathbf{- 1}}\right)$ \\
\hline 1 & Plot C & 961.50 \\
\hline 2 & Plot A & 857.64 \\
\hline 3 & Plot B & 760.72 \\
\hline 4 & Plot D & 625.01 \\
\hline
\end{tabular}

Table-3: Regeneration Potential of Species in Old Afaka Forest Reserve

\begin{tabular}{|l|l|l|l|l|l|}
\hline S/N & Species & Plot A & Plot B & Plot C & Plot D \\
\hline 1 & Prosopis africana & 0.00 & 0.00 & 0.00 & 0.03 \\
\hline 2 & Entada Africana Gull \&Perr. & 0.01 & 0.00 & 0.00 & 0.00 \\
\hline 3 & Vitex doniana Linn. & 0.00 & 0.00 & 0.00 & 0.01 \\
\hline 4 & Terminalia avicennoides Guill \&Perr. & 0.05 & 0.02 & 0.01 & 0.02 \\
\hline 5 & Macaranga hurifolia & 0.00 & 0.00 & 0.00 & 0.00 \\
\hline 6 & Triplochiton scleroxylone K.Schum & 0.00 & 0.00 & 0.00 & 0.00 \\
\hline 7 & Isoberlinia doka Craib\&Stapf. & 0.44 & 0.75 & 0.76 & 0.68 \\
\hline 8 & Annona senegalensis Pers. & 0.00 & 0.05 & 0.00 & 0.00 \\
\hline 9 & Carissa adolia Linn. & 0.01 & 0.00 & 0.00 & 0.00 \\
\hline 10 & Pilostigma thornningii (schum) & 0.00 & 0.00 & 0.03 & 0.00 \\
\hline 11 & Acacia senegal (Houtt) & 0.03 & 0.02 & 0.04 & 0.01 \\
\hline 12 & Lophira lanceolata Banks ex Gaertn. & 0.01 & 0.00 & 0.00 & 0.00 \\
\hline 13 & Combretum ghasalense Engl.\& Diels & 0.01 & 0.00 & 0.01 & 0.00 \\
\hline 14 & Parkia biglobosa (Jacq) Benth & 0.02 & 0.04 & 0.01 & 0.02 \\
\hline 15 & Parinari curatellifolia Planch. & 0.00 & 0.02 & 0.00 & 0.00 \\
\hline
\end{tabular}


Table-4: Relative Frequency of Species in Old Afaka Forest Reserve

\begin{tabular}{|l|l|l|l|l|l|}
\hline S/N & Species & Plot A & Plot B & Plot C & Plot D \\
\hline 1 & Terminalia avecinnoides Guill \&Perr. & 5.850 & 8.492 & 6.462 & 8.739 \\
\hline 2 & Khaya senegalensis Ders. & 0.278 & 0.450 & 0.303 & 0.000 \\
\hline 3 & Vitellaria paradoxa C.F. Gaertn & 0.543 & 1.046 & 1.256 & 1.817 \\
\hline 4 & Pilostigma thonningii(schum) & 4.403 & 2.063 & 5.229 & 2.008 \\
\hline 5 & Annona senegalensis Pers. & 8.951 & 3.487 & 7.757 & 0.000 \\
\hline 6 & Acacia Senegal(Houtt) & 67.208 & 56.010 & 46.644 & 45.372 \\
\hline 7 & Lannea barteri (Oliv) & 1.733 & 0.699 & 0.000 & 1.205 \\
\hline 8 & Gardenia imperialis( K.Schum) & 1.338 & 5.846 & 0.000 & 1.012 \\
\hline 9 & Carissa adolia Linn. & 4.703 & 1.848 & 5.687 & 2.460 \\
\hline 10 & Sterculia setigera Del. & 1.538 & 7.946 & 0.000 & 6.422 \\
\hline 11 & Isoberlinia doka Craib\&Stapf. & 8.188 & 20.541 & 7.653 & 14.879 \\
\hline 12 & Entada Africana Gull \& Perr. & 0.349 & 0.320 & 0.000 & 0.904 \\
\hline 13 & Diospyros mespiloformis Hochst. & 0.368 & 0.000 & 0.000 & 0.304 \\
\hline 14 & Prosopis Africana (Gull \& Perr) Taub & 0.412 & 0.000 & 0.000 & 0.000 \\
\hline 15 & Combretum ghasalens Engl.\& Diels & 0.288 & 1.139 & 0.000 & 0.000 \\
\hline 16 & Anogeisus liocarpus(DC) Gull \&Perr & 6.850 & 0.000 & 0.000 & 0.501 \\
\hline 17 & Parkia biglobosa(Jacq) Benth & 5.465 & 0.000 & 0.00 & 0.000 \\
\hline 18 & Triplochiton scleroxylon K.Schum. & 0.890 & 0.000 & 1.711 & 0.000 \\
\hline 19 & Vitex doniana Linn & 0.890 & 0.000 & 1.811 & 1.306 \\
\hline 20 & Strychnos spinosa Lam. & 0.418 & 0.000 & 2.005 & 0.000 \\
\hline 21 & Tectona grandis L.f. & 2.256 & 0.000 & 0.000 & 1.605 \\
\hline 22 & Macaranga hurifolia Beille. & 0.000 & 9.692 & 1.247 & 6.745 \\
\hline 23 & Parinari curitellifolia Planch. & 0.000 & 0.460 & 0.000 & 0.604 \\
\hline 24 & Lophira lanceolata Banks ex Gaertn & 0.000 & 0.560 & 2.467 & 0.000 \\
\hline 25 & Lawsonia inermis L. & 0.000 & 0.256 & 7.242 & 0.000 \\
\hline 26 & Psidium guajava L. & 0.000 & 0.350 & 0.303 & 1.705 \\
\hline 27 & Irvingia gabonensis(Bail) & 0.000 & 1.089 & 1.543 & 1.309 \\
\hline & & & & \\
\hline
\end{tabular}

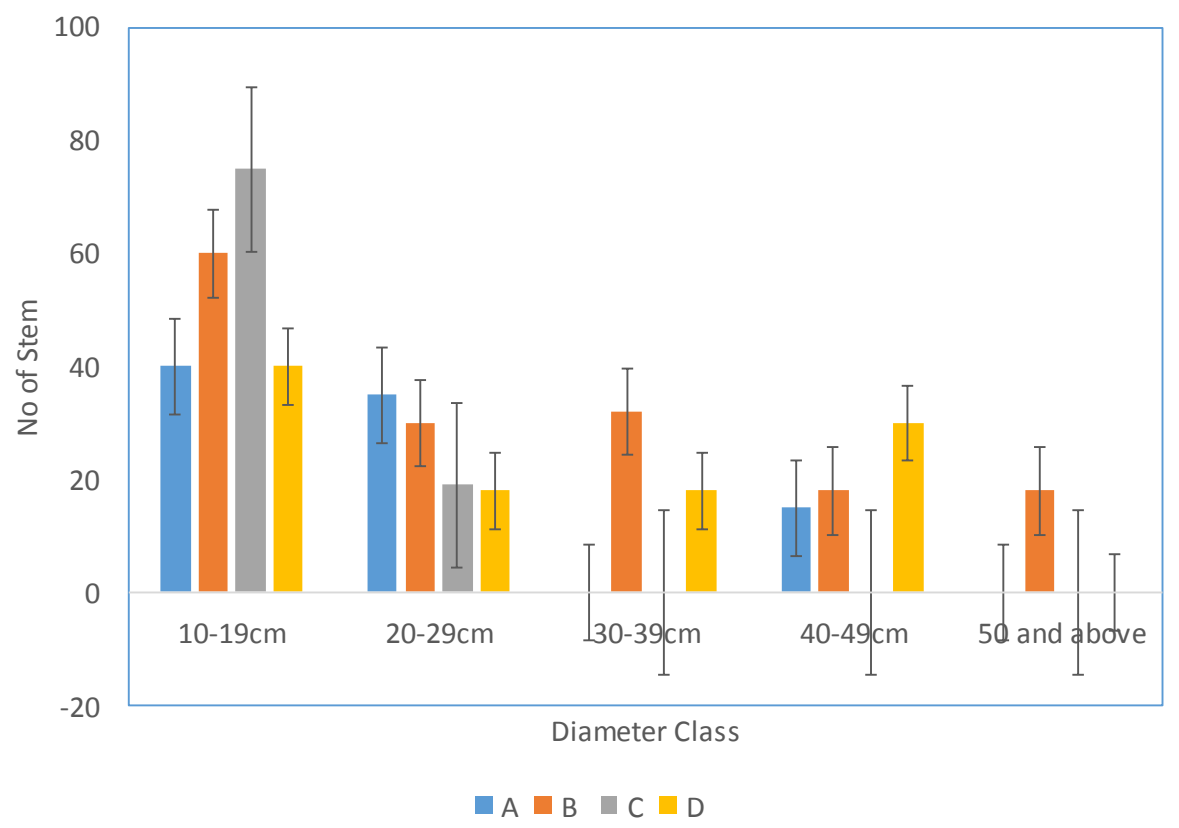

Fig-1: Diameter Class distribution of woody stem in plot A, B, C and D of Old Afaka Forest Reserve

\section{Regeneration Potentials}

The regeneration potential of the diversified species as indicated in Table- 3 is very poor. It therefore, has a great implication for regeneration and conservation of the various species encountered. Isoberlinia doka had the highest regeneration potential from each of the examined plots in Old Afaka Forest Reserve; followed by Acacia senegal, Parkia biglobosa and Terminalia avicennoides. However, most of the important woody plants of economic importance like 
Triplochiton scleroxylon, had zero regeneration potential. Regeneration potential of the most species is zero, owing to complete absent of mother trees which would have produced the wildlings within the assessed area. The results are in consonance with the works and observations of Oduwaiye et al., [13]; Sodimu et al., [29]; Sodimu et al.,[10].

\section{Relative Frequency}

In Table-4 plots A, B, C and D, 21, 19, 16 and 18 species were observed. In plot A, Acacia senegal showed the greatest occurrence with relative frequency of $67.2 \%$, the species had some spread in plot B, plot C and plot D with relative frequency of $56 \%, 46.6 \%$ and $45.4 \%$. This was followed by Isoberlinia doka in plots B and plot D with relative frequency of $20.5 \%$ and $15.9 \%$ respectively. However, in plot C Acacia senegal was closely followed by Annona senegalensis with relative frequency of $7.56 \%$ respectively. This is in agreement with the work of Sodimu et al., 2020 [10] who observed that I. doka and A. senegal have better spread in Northern Guinea Savannah eco-zone.

\section{CONClusion AND RECOMMENDATION \\ Conclusion}

None of the tree species in protected area of Old Afaka Forest Reserve was observed flowering during the period of assessment. However, it could not be ascertained whether most of the diverse species had undergone generative phase or were still undergoing vegetative phase. From the analysis, it would be observed that most of the woody species were not regenerating themselves. There were cases when mother trees of the wildlings observed were absent from the plots or the wildlings of woody species were absent. This situation poses a great threat to conservation of the diverse species in the Forest Reserve.

\section{Recommendation}

Based on the findings, it is recommended that it is of paramount importance to understand the phenology of the forest reserve and, to study whether seed or fruits produced are under adequate physiological conditions to germinate and grow into wildlings for regeneration purpose. Otherwise, it will be very necessary to find means of regenerating the reserve either artificially or naturally for sustainability of the forest reserve.

\section{REFERENCE}

1. Attiwill, P. M. (1991). The Disturbance of Forest Ecosystems: The Ecological Basis for Conservative Management. For Ecol Manag. 63:247-300.

2. Borowski, T. (2015). Modifications of Natural Rubber (Hevea brasiliensis): Production, Application and Comparison. International journal of World Scientific News, 20-52

3. Magaii, Y., Ajibade, G. A., Yilwa, V. M., Appah, J., Haroun, A. A., Alhaji, I., Umadi, M. M. \& Sodimu, A. I. (2019). Concentration of Heavy Metals in the Soil and Translocation with Phytoremediation Potential by Plant species in Military Shooting Range. International Journal of World Scientific News. 92(3):260-271.

4. Franklin, J. F. (1993) Preserving biodiversity Species, Ecosystems, or Landscapes? Ecol Appl. 34:202-205.

5. Larsen, D. L., Shiftly, R., Thomson, F. R., Bokkshire, B. L., Dey, D. C., Kurzejeski, E. W., \& England, K. (1997). Ten Guidelines for Ecosystem Researchers: Lessons from Missouri. J For. 95:4-8.

6. Hunter, M. L. (1993). Natural fire regimes as spatial models for managing boreal forests. Biol Conserv. 65:115-120.

7. Bergeron Y, Leduc, A., Harvey, B., \& Gauthier, S. (2002). A Guide for Sustainable Management of the Canadian Boreal Forest. Silva. Fenn. 36:81-95.

8. Sobamowo, G., Kamiyo, O. M., \& Adeoye, O. A. (2019). Temporal Variation ion in Species Composition Diversity and Regeneration Status Along Altitudinal Gradient Slope. International Journal of World Scientific News. 138:2:167-191.

9. Bergeron, Y., \& Harvey, B. (1997). Basing Silviculture on Natural Ecosystem Dynamics: An Approach Applied to the Southern Boreal Mixed Wood Forest of Quebec. For Ecol Manag. 92:235-242.

10. Sodimu, A. I., Sulaiman, R. A., Maikano, S., \& Lapkat, G. L. (2020). Assessment of Species Diversity and Potentiality in Buruku Forest Reserve, Kaduna State, Nigeria. Asian Journal of Research in Agriculture and Forestry. 5(1):39-46.

11. Nguyen-Xuan, T., Bergeron, Y., Simard, D., Fyles, J. W., \& Pare, D. (2000). The importance of Forest Floor Disturbance in the Early Regeneration Patterns of the Boreal Forest of Western and Central Quebec: A Wildfire Versus Logging Comparison. Can. J For Res. 30:1353-1364.

12. Ogunkalu, O. A., Sodimu, A. I., Suleiman, R. A., \& Adedire, O. O. (2017). Survey of benefits and Constraints or Urban Trees in Kaduna Metropolis. International Journal of World News of Natural Sciences, 2: 19-27. www.woldnewsnaturalsciences.com

13. Oduwaiye, E. A., Oyeleye, B., \& Oguntala, A. B. (2002). Species diversity and potentiality for forest regeneration in Okomu permanent sample plot. Proceeding of the $28^{\text {th }}$ Annual conference of the Forestry Association of Nigeria. 264-269. 
14. Sodimu, A. I., Onwumere, G. B., \& Yilwa, V. M. (2019). Assessment of Soil Based Heavy Metals from Anthropogenic Activities in Kaduna Guinea Savanna of Nigeria. International Journal of World Scientific News. 125:83-93.

15. Raychaudhuri, D., Saha, S., Sen, S., \& Dhali, D. C. (2015). Spiders (Araneae: Arachnida) of Reserve Forests of Dooars: Gorumara National Park, Chapramari Wildlife Sanctuary and Mahananda Wildlife Sanctuary. World Scientific News, (20), 1-339.

16. Sodimu, A. I., Onwumere, G. B., \& Yilwa, V. M. (2019). Soil Based Heavy Metals Originating from Anthropogenic Activities on Floristic Composition of Some Selected Sites in Kaduna Northern Guinea Savanna of Nigeria. Asian Journal of Environment and Ecology. 10(4);1-10.

17. Areola, O. E. (1991). Ecology of Natural Resources in Nigeria. CAB. 278.

18. Van der maarel, E. (1996) Pattern and Process in Plant Community: Fifty Year After A. S. Watt. Journal of Vegetation Science. 7: 19-28.

19. Nigerian Environmental Study Team Nigeria's Threatened Environment. (1991) A National Research Profile. Nigerian Environmental Study/Action Team (NEST), Ibadan, Nigeria. 287-290.

20. IUCN World Conservation Strategy. (1980). Living Resources conservation for Sustainable Development -IUCNUNEP-WWF 1980.

21. Gabriel, A. A., \& Adedapo, A. A. (2017). Exotic Versus Indigenous and Implication for Environmental Forestry Management in the Niger Delta, Nigeria. International Journal of World Scientific News. 74:36-5.

22. Norton, T. W. (1996) Conservation of biological diversity in temperate and boreal forest ecosystems. For Ecol Manag. 85:1-7.

23. Hansen, A. J., Spies, T. A., \& Swanson, F. J. (1991). Conserving Biodiversity in managed Forests Lessons from Natural Forests. Bioscience. 41:382-392.

24. Selmants, P. C., \& Knight, D. H. (2003). Understory Plant Species Composition 30-50 years After Clear Cutting in Southeastern Wyoming Coniferous Forests. Forest Ecology Management. 185: 275-289.

25. Sodimu, A. I., Yilwa, V. M., \& Onwumere. G. B. (2017). The Impact of Gas Flaring from Kaduna Refining and Petrochemical Company (KRPC) on Plant Diversity in Kaduna Northern Guinea Savanna Eco-Region of Nigeria. International Journal of World Scientific News. 69:168-178.

26. Otegbeye, G. O., Owonubi, J. J., \& Oviasuyi, P. K. (2001). Interspecific variation growth of Eucalyptus growing in northern Nigeria. In Proceeding of 27th Annual conference of Forest Association, Nigeria (pp. 12-16).

27. National Population Commission. (2006). National Population Commission (N.P.C.) News Bulletin, Kaduna State. 13-15.

28. Cuttam, G., \& Curtis J. T. (1956). Use of Distance Measure in Phytosociological Sampling. Ecology, 37:451-460.

29. Sodimu, A. I., Ogunkalu, O. A., Komolafe, A. S., \& Sadiq, Z. K. (2017). Economic Analysis of Wonderful Kola (Hydrocotyle asiata) Marketing in Kaduna North Local Government Area of Kaduna State, Nigeria. International Journal of World News of Natural Sciences. (9):1-6. 